\title{
Virtual Reality (VR) Media Distraction Relieve Anxiety Level of the Children During Circumcision
}

\author{
$1^{\text {st }}$ Andan Firmansyah \\ Diploma III of Nursing, STIKES \\ Muhammadiyah Ciamis \\ Ciamis, West Java, Indonesia \\ andan.rock@gmail.com \\ $4^{\text {th }}$ Tita Rohita \\ Faculty of Health Sciences \\ STIKES Muhammadiyah Ciamis \\ Ciamis, West Java, Indonesia
}

\author{
$2^{\text {nd }}$ Henri Setiawan \\ Diploma III of Nursing, STIKES \\ Muhammadiyah Ciamis \\ Ciamis, West Java, Indonesia \\ $5^{\text {th }}$ Afriza Umami \\ Diploma III of Medical Record, STIKES \\ Muhammadiyah Bojonegoro \\ Bojonegoro, East Java, Indonesia
}

\author{
$3^{\text {rd }}$ Daniel Akbar Wibowo \\ Faculty of Health Sciences \\ STIKES Muhammadiyah Ciamis \\ Ciamis, West Java, Indonesia
}

\begin{abstract}
Circumcision is a minor surgical that will be experienced by every child, especially a Muslim child because It was related religious commandment with. Most children appear to be quite anxious about circumcision. Virtual Reality (VR) Distraction is one of the methods of Researcher to relieve anxiety level of the children during circumcision processes. Virtual Reality (VR) distraction is a type of audio-visual distraction with Google VR tool which helps children divert unpleasant stimuli and make feel relaxed in a familiar environment. The objective of this research is to measure effectiveness of VR distraction in to anxiety level of the children during circumcision. This research is quantitative research that used quasi experimental with control group design. Number of samples are 60 children which divided into 2 groups (treatment group [ $n=30$ respondents] and control group [ $n=30$ respondents]). Anxiety and Fear level was measured by Hamilton Anxiety Rating Scale (HAM-A) and Face Fear Scale also Pulse Oximetry (Objective fear Symptoms). The result of this research indicated that VR Distraction was effective to relieve Anxiety Level during circumcision $(p$ value $=0.000$ ) This research was concluded that VR Distraction is useful to relieve anxiety level of children during circumcision with guide imagery mechanism. Keywords: virtual reality, anxiety level, fear level, circumcision, guide imagery.
\end{abstract}

Keywords-Virtual Reality, Media, Anxiety, Children

\section{INTRODUCTION}

Childhood is the most influential period of the human life cycle, because the experiences that occur at this time will be the basis at the next stage, namely the process of growth and development. Various concepts are studied by children at this time, one of them is the concept of aches and pains [1]. Anxiety is a subjective experience in the form of uncomfortable feelings arising from unspecified causes, one of the things that can cause anxiety is an invasive action by health workers, including surgical procedures [2]. Exposure to pediatric surgical procedures is a relatively common and significant stressor for children. It is estimated that up to 5 million children undergo elective surgical procedures in North America each year, and nearly $75 \%$ of them experience considerable preoperative anxiety [3]. Anxiety is a common and natural thing that happens to someone who will undergo a surgical procedure, especially if the child is going to live it. Minor surgical procedures can cause significant anxiety, especially if in children [4]. Surgery can produce emotional distress and trauma for children and their families if they are not psychologically prepared.

Extreme anxiety can increase the risk of surgical complications [5]. To date there are about 200 preoperative trials, including the provision of behavioral change interventions (cognitive interventions) to reduce anxiety during surgery. This intervention aims to influence how a person thinks, for example using distraction techniques, which is to shift the focus of attention from surgery and positive thinking. One of these cognitive interventions is the use of audio visual [4]. In another study by Angela Li [6] concluded that using virtual reality during intra operative procedures can reduce patient anxiety.

Circumcision is a surgical procedure by cutting all or part of the penile preputium for indications and for a specific purpose, which is also one of the most common surgical procedures in the world and has for years been controversial by questioning medical indications especially in male infants who newborn [7]. Circumcision (circumcision) is one of the minor surgical procedures that are generally performed in children in Indonesia, because it is a religious requirement that requires the circumcision of a Muslim, especially preaged children school. A study at the Circumcision Resource Center, Boston, Massachusetts, USA states that circumcision can cause trauma to children. Research on school-age children, states that circumcision is perceived by children as an aggressive attack on the body that damages him [8]. Most of the children who undergo circumcision show signs of anxiety that are not mild. This is indicated by some of the children showing pale faces of fear, sweating, rigid 
extremities and increased pulse. Until now, there have not been many specific studies regarding the handling of child anxiety during circumcision, so research on anxiety reduction methods in preschool-aged children undergoing circumcision using virtual reality distraction techniques can be used as one of the scientific developments in handling child anxiety during minor surgical procedures, especially circumcision

\section{METHOD}

This research is a quantitative study using quasi experimental with pretest posttest control group design [9]. The population in this study were preschool children who were undergoing circumcision in the districts of Ciamis and Tasikmalaya in November as many as 84 children. The independent variable in this study is the audio visual distraction technique using google virtual reality (VR), while the dependent variable is the level of anxiety. The research sample was obtained using accidental sampling technique with a large sample of 60 people divided into 2 groups: the treatment group ( 30 people) who will be given a virtual reality intervention distraction in the form of watching cartoons using Google VR and the control group (30 people) were not given any treatment only given treatment like circumcision in general. The instrument used in this study was the Hamilton Anxiety Rate Scale (HAMA) to measure children's anxiety and facial scales to measure how much the child's anxiety was according to himself (subjective measurement) and fingertip pulse oximeter to calculate the pulse rate per minute (measurement in objective), while the instrument used in the treatment in this study is Google Virtual Reality (VR) which consists of a 360-degree realistic animated video containing audio-visual content that is loved by children.

Respondents in the control group and the treatment group were measured subjectively and objectively with anxiety levels just prior to the circumcision. Then finally when the circumcision procedure has been completed. The data obtained is then tabulated and analyzed. Data analysis in this study used the Wilcoxon Mann Whitney U Test and Independent t-Test with the significance value $\alpha \leq 0.05$.

\section{RESULT}

TABLE I. ASSESSMENT RESULTS AND TESTS FOR ANXIETY LEVELS IN THE CONTROL AND TREATMENT GROUPS

\begin{tabular}{|c|c|c|c|c|}
\hline \multirow[t]{2}{*}{ No. } & $\begin{array}{l}\text { Control } \\
(\mathrm{n}=30)\end{array}$ & \multicolumn{3}{|c|}{$\begin{array}{c}\text { Treatment } \\
(\mathrm{n}=30)\end{array}$} \\
\hline & Pre & Post & Pre & Post \\
\hline \multirow[t]{4}{*}{ Mean HAM-A } & 20,33 & 18,23 & 19,66 & 12,23 \\
\hline & \multicolumn{4}{|c|}{ Statistical Analysis Results $(\mathrm{p}=0,000)$} \\
\hline & $\begin{array}{c}\text { Control } \\
(\mathrm{n}=30)\end{array}$ & & \multicolumn{2}{|c|}{$\begin{array}{c}\text { Treatment } \\
(\mathrm{n}=30)\end{array}$} \\
\hline & Pre & Post & Pre & Post \\
\hline \multirow[t]{4}{*}{$\begin{array}{l}\text { Mean Anxiety } \\
\text { Face Scale } \\
\end{array}$} & 3,43 & 2,86 & 3,26 & 1,06 \\
\hline & \multicolumn{4}{|c|}{ Statistical Analysis Results $(\mathrm{p}=0,000)$} \\
\hline & $\begin{array}{c}\text { Control } \\
(\mathrm{n}=30)\end{array}$ & & \multicolumn{2}{|c|}{$\begin{array}{l}\text { Treatment } \\
(\mathrm{n}=30)\end{array}$} \\
\hline & Pre & Post & Pre & Post \\
\hline \multirow[t]{2}{*}{ Mean Pulse } & 104,77 & 98,87 & 105,50 & 83,75 \\
\hline & \multicolumn{4}{|c|}{ Statistical Analysis Results $(\mathrm{p}=0,000)$} \\
\hline
\end{tabular}

Source: Primary

Table I. shows that the results of measurement of anxiety level subjectively using (HAM-A scale) and the Face Anxiety Scale between the control group and the treatment group showed significant differences and changes with the results of statistical tests with a value $p=0,000$. In addition, the difference in anxiety level changes measured objectively (beats per minute) using a fingertip pulse oximeter between the control group and the treatment group showed a significant difference with the statistical test results value $p$ $=0,000$.

The average anxiety value according to HAM-A decreased in the treatment group from 19.66 to 12.23 while in the control group it also decreased but not too significantly from 20.33 to 18.23 while on the face scale in the treatment group the average anxiety scale value from 3.26 to 1.06 and at treatment group from 3.43 to 2.86 . The pulse measurements for the treatment group showed a significant decrease from 105.50 to 83.75 . In the control group there was also a decrease in the mean value but it was not too significant from 104.77 to 98.87 .

\section{DISCUSSION}

Based on the results of the study, it was found that all respondents in the control group and the treatment group experienced varying levels of anxiety, both assessments subjectively and objectively. That is because children's perceptions and motivations in dealing with circumcision are different. Some children may feel happy, because circumcised children will feel more mature and there is a habit that after circumcision the child will receive gifts from parents, family and the community around where he lives. Some may consider circumcision as a compulsion that would hurt him. According to the theory that circumcision can be perceived by school-age children as an aggressive attack on the body that damages him, will damage the ego, release fear of castration and change reality to them [10]

According to [5] states that the level of subjective anxiety a person is not always associated with the seriousness of the surgical procedure, this is evident in some respondents in this study felt experiencing severe levels of anxiety (scale 4) when the circumcision procedure will begin, even though the circumcision only includes minor 
surgery. In the first measurement of the level of anxiety objectively using pulse measurements per minute, the average pulse rate per minute was obtained. This is due to the physiological response of anxiety in the form of an increase in pulse rate per minute [11]. Different levels of anxiety in each child are caused by each human's response to stressors is different. This is in accordance with the cognitive model of anxiety presented by [12] which states that different responses in each individual are influenced by, among others, the weaknesses in various information processes. Another cause that affects different levels of anxiety is the existence of a support system that is the assistance of parents or the closest person of the child so that children respond differently to stressors. In some children who experience an increased level of anxiety, this can be due to the pain felt during local anesthesia and the increased fear during surgery related to tools and officers who perform the surgery, especially in the first 5 minutes this is one of the causes of the child experiencing an increase pulse and scream at that moment.

Based on the results of the study, it was found that there were significant differences in anxiety levels between pretest and post-test in groups of pre-school children who were given virtual reality distraction techniques during circumcision. This means that the administration of distraction techniques has proven to be effective in reducing children's anxiety both subjectively and objectively. The results of statistical analysis found a significant decrease in anxiety levels between groups of children who were given virtual reality distraction techniques during circumcision and groups of school-age children who were not given virtual reality distraction techniques during circumcision. This is consistent with the theory that one way that can be done to control anxiety is an audio visual distraction technique using virtual reality to distract children. From the analysis conducted by the author, the distraction of attention on video content in virtual reality google (VR) that is liked by children will cause children to no longer think about the circumcision procedures performed on him so that he becomes calmer. Children become happy and comfortable so that it affects the whole system that occurs in the body. Thus the child becomes relaxed and less anxiety. Distraction technique is thought to increase descendant inhibition so that it can fight anxiety which tends to decrease descendant inhibition [13]. The existence of distraction techniques can inhibit the work of the sympathetic nervous system, the production of neurotransmitters is inhibited so that the pulse, blood pressure and other physiological responses which are signs of anxiety can return to normal. Other factors that can contribute to the success of this virtual reality distraction technique include the age of the child, older children becoming more cooperative so that it is easy for researchers to ask children to use Google's virtual reality during the circumcision procedure. In addition, the assistance of parents or the closest person of the child makes children feel calmer so that distraction techniques become more effective.

\section{CONCLUSION}

Conclusions Distraction techniques using Google virtual reality (VR) can reduce anxiety levels which are marked by a significant decrease in the anxiety scale HAM-A and Face
Fear Scale and a decrease in pulse rate per minute. Suggestion Researchers suggest that virtual reality distraction techniques can be applied to circumcision measures clinics by health practitioners both medical and nursing so that children's anxiety can be minimized and further research on the effect of applying virtual reality distraction techniques can be done with wider parameters, greater age of the child big like school age 7-9 years and or in other invasive procedures.

\section{ACKNOWLEDGMENT}

This research was supported by D3 Nursing Study Program Muhammadiyah Ciamis STIKes. We thank our colleagues who provided insights and expertise that greatly helped the research and all interpretations / conclusions from this paper. We thank Mr. Suhanda and Mr. Dedi Supriadi from the D3 Nursing Study Program at STIKes Muhammadiyah Ciamis for helping with circumcision activities in his clinic as well as in mass circumcision activities in Rajadesa.

\section{REFERENCES}

[1] Wong, D. L., Hockenberry, M., Wilson, D., Winkelstein, M. L., \& Schwartz, P. (2002). Buku Ajar Keperawatan Pediatrik Wong, Ed 6, Vol I. Alih Bahasa Agus Sutarna. Jakarta: EGC.

[2] Ramaiah, S. (2003). Kecemasan, bagaimana mengatasi penyebabnya. Yayasan Obor Indonesia.

[3] Perry, J. N., Hooper, V. D., \& Masiongale, J. (2012). Reduction of preoperative anxiety in pediatric surgery patients using ageappropriate teaching interventions. Journal of PeriAnesthesia Nursing, 27(2), 69-81.

[4] Chow, C. H., Van Lieshout, R. J., Schmidt, L. A., Dobson, K. G., \& Buckley, N. (2016). Systematic Review: Audiovisual Interventions for Reducing Preoperative Anxiety in Children Undergoing Elective Surgery. Journal of pediatric psychology, 41(2), 182-203. doi:10.1093/jpepsy/jsv094

[5] Kozier,B.,Glenora Erb, Audrey Berman dan Shirlee J.Snyder. (2010). Buku Ajar Fundamental Keperawatan ( Alih bahasa : Esty Wahyu ningsih, Devi yulianti, yuyun yuningsih. Dan Ana lusyana ). Jakarta :EGC

[6] Li, A., Montaño, Z., Chen, V. J., \& Gold, J. I. (2011). Virtual reality and pain management: current trends and future directions. Pain management, 1(2), 147-157. doi:10.2217/pmt.10.15

[7] Evangelista, T., Widodo, D., \& Widiani, E. (2016). Pengaruh Hipnosis 5 Jari Terhadap Tingkat Kecemasan Pasien Sirkumsisi Di Tempat Praktik Mandiri Mulyorejo Sukun Malang. Nursing News: Jurnal Ilmiah Keperawatan, 1(2).

[8] Goldman, R. (1999). The psychological impact of circumcision. BJU international, 83(S1), 93-102.

[9] Dahlan, M. S. (2011). Statistik untuk kedokteran dan kesehatan. Penerbit Salemba.

[10] Özkıdık, M., Sayın, Z. E., Coşkun, A., Asutay, M. K., Bahçeci, T., \& Bozac1, A. C. (2018). Psychological Impact of Non-therapeutic Circumcision on School Boys.

[11] Keliat, B. A. (1999). Penatalaksanaan stres. Jakarta: Penerbit Buku Kedokteran: EGC.

[12] Kaltenthaler, E., Brazier, J., De Nigris, E., Tumur, I., Ferriter, M., Beverley, C., ... \& Sutcliffe, P. (2006). Computerised cognitive behaviour therapy for depression and anxiety update: a systematic review and economic evaluation. In NIHR Health Technology Assessment programme: Executive Summaries. NIHR Journals Library.

[13] Świeboda, P., Filip, R., Prystupa, A., \& Drozd, M. (2013). Assessment of pain: types, mechanism and treatment. Pain, 2(7).

[14] Cansever, G. (1965). Psychological effects of circumcision. British Journal of Medical Psychology, 38(4), 321331. https://doi.org/10.1111/j.2044-8341.1965.tb01314.x 
[15] Firmansyah, A. (2018). Orientation Relationship With Anxiety Level In The Treatment Of Patients Floor Orchid Ii Hospital Polewali. Bina Generasi: Jurnal Kesehatan, 7(1), 35-42.

[16] Gazal, G., Fareed, W. M., \& Zafar, M. S. (2015). Effectiveness of gaseous and intravenous inductions on children's anxiety and distress during extraction of teeth under general anesthesia. Saudi journal of anaesthesia, $9(1), 33$.

[17] M Hamilton. The Assessment of Anxiety States by Rating. $32 \mathrm{Br}$ J Med Psychol 50-55. 1959.

[18] Maier, W., Buller, R., Philipp, M., \& Heuser, I. (1988). The Hamilton Anxiety Scale: reliability, validity and sensitivity to change in anxiety and depressive disorders. Journal of affective disorders, 14(1), 61-68.

[19] Rosmiati, R., Mustofa, A. H., Awida, H. S., \& Setiawan, H. (2018). THE RELATIONSHIP BETWEEN THE USE OF GADGETS WITH THE SOCIAL DEVELOPMENT OF PRESCHOOL CHILDREN. In International Seminar Rural Urban and Community Health (ISRUNCH) (Vol. 1, No. 1).

[20] Wahyuni, H., Setyawati, S., \& Inayah, I. (2015). Terapi Slow Deep Breathing Dengan Bermain Meniup Baling-Baling Terhadap Intensitas Nyeri Pada Anak Yang Dilakukan Penyuntikan Anestesi Sirkumsisi. Jurnal Skolastik Keperawatan, 1(2), 36-43. 